\title{
PERAN KEPALA KELUARGA DALAM MEMBENTUK KARAKTER RELIGIUS REMAJA DI DESA LAMPUYANG KABUPATEN KOTA WARINGIN TIMUR
}

\author{
Khairul Akbar', Eddy Lion², \& Ahmad Saefulloh ${ }^{3}$ \\ Program Studi PPKn Jurusan Pendidikan Ilmu Pengetahuan Sosial \\ Universitas Palangka Raya \\ E-mail: khairulakbar097566@gmail.com¹ , eddylion@gmail.com² , \& saefulloh@fkip.upr.ac.id ${ }^{3}$
}

\begin{abstract}
Abstrak
Penelitin ini bertujun untuk mengetahui peran kepala keluarga dalam membentuk karakter religius remja serta mengetahui faktor pengehambat dan pendukung kepala keluarga dalam membentuk karakter religius remaja di desa Lampuyang Kabupaten Kota Waringin Timur. Penelitian ini menggunakan penelitin deskritif pendekatan kualitatif dengan teknik pengumpulan data menggunakan metode observasi, metode wawancara, dan metode dokumentasi. Informan dalam penelitian ini adalah kepala keluarga terdiri dari 10 informan, terdiri dari 5 kepala keluarga beragama Kristen, dan 5 kepala keluarga beragama Islam. Hasil penelitian menunjukkan bahwa : 1) Peran kepala keluarga dalam membentuk karakter religius di desa Lampuyang Kabupaten Kota Waringin Timur yaitu dengan memperkenalkan tentang pengetahuan agama, mengajarkan kebiasan baik, mengajakbuntuk membiasakan hal-hal baik, sampai dengan mengingatkan apabila ada kesalahan ataupun kekurangan dalam sistem penerapannya ; 2) faktor penghambat dan dukung kepala keluarga dalam membentuk karakter religius remaja di desa Lampuyang Kabupaten Kota Waringin Timur yaitu factor penghambatnya adalah konsistensi, sikap remaja yang masih labil, pengaruh zaman dan kemajuan teknologi, sedangkan faktor pendukungnya adalah adanya dukungan dari orang tua, lingkungan, dan adanya guru. Adapun cara kepala keluarga dalam menangani faktor penghambat dalam membentuk karakter religious remaja yaitu melalui komunikasi yang baik terhadap remaja sertavmempunyai rasavkonsisten terhadap apa yang ingin dilaksanakan, sehingga dapat melakukan filtrasi terhadap perkembangan zaman dan menumbuhkan keinginan remaja untuk belajar lebih baik sehingga remaja-remaja mempunyai karakter yang lebih baik dan berguna bagi bangsa dan negara. Kata Kunci: Peran Kepala Keluarga dan Karakter Religius
\end{abstract}

\begin{abstract}
This study aims to determine the role of the head of the family in shaping the religious character of adolescents and to determine the inhibiting and supporting factors the head of the family in the formation of the religious character of adolescents in Lampuyang Village, East Waringin City Regency.

This study uses adescritive qualitative aaproach with data collection techniques using observation methods, interview methods, and documentation methods. The informants in this study were heads of families consisting of 10 informants, consisting of 5 hads of families who were Cristian, and 5 heads of families whobwere Muslim. The result showed that: 1) the role of the head of the family in shaping religious character in Lampuyang Village, Kota Waringin Timur District, namely by introducing religious knowledge, teaching good habits, inviting people to get used to good things, to remind them if there are erros of deficiencies in the implementation of system; 2). The inhibiting and supporting factors of the head of the family in shaping the religious character of adolescent in Lampuyang village, East Waringin City Regency, namely this inhibinting factors are technological progress, while the supporting factors are support from parents, the environment, and teacher. The way the head of family overcomes the inhibiting factors in shaping the religious character of adolenscents in through good communication with adolendcents and having a consistens sense of wht they want to do, so thar they can filter the development of the times and foster that desire. Teenagers to learn better so that teenagers have good character. Better and beneficial for the nation and state.
\end{abstract}

Keywords: Role of Family Head and Religious Character 


\section{PENDAHULUAN}

Keluarga merupakan sebagian unit terkecil dari sebuah masyarakat yang terdiri dari kepala keluarga dan beberapa orang yang terkumpul dan tinggal disuatu tempat dibawah satu atap dalam keadaan saling ketergantungan (Effendy, 2005). kepala keluarga ini merupakan orang yang bertanggung jawab atas anggota keluarganya atas kebutuhan sehari-hari, yang mempunyai peran penting dalam keluarga seperti halnya dalam mendidik anak yang sudah bisa dikatakan remaja, tentu peran kepala keluarga sangat dibutuhkan dalam medidik remaja terkhususnya dalam membentuk karakter remaja mengingat sekarang bahwa banyak sekali permasalahan yang terjadi pada saat ini tidak usah jauh-jauh kita melihat Berdasarkan realitas yang ada. Diera globalisasi ini remaja-remaja sekarang cenderung kehilangan karakternya dan mengalami degaradasi moral serta etika yang kurang baik dalam bermasyarakat.

\section{Menurut Ahmad Amin dalam} www.liputan6.com pengertian etika adalah sebagai berikut: "etika merupakan suatu ilmu yang menjelaskan tentang arti baik dan buruk serta apa yang seharunya dilakukan manusia, juga menyatakan sebuah tujuan yang harus dicapai manusia dalam perbuatannya dan menunjukan arah untuk melakukan apa yang seharusnya dilakukan manusia."

Adapun terkait dengan remajaremaja di desa Lampuyang masih melakukan hal-hal yang kurang mengenakan dan tidak nyaman dipandang, dan khususnya terkait permasalahan etika didesa Lampuyang Kabupaten Kota Waringin Timur, Mustadi 2021 mengatakan dalam observasi penelitian bahwa remaja-remaja di desa Lampuyang pada umumnya memang masih mengonsumsi obat-obatan, minumminuman, terlebih lagi memakai narkotika, melakukan kekerasan, serta melakukan hubungan seks diluar pernikahan, tentu hal-hal seperti inilah yang meresahkan masyarakat pada umumnya dikarenakan bisa menimbulkan suatu kericuhan dan kerugian didalam sebuah masyarakat, seperti halnya yang terjadi ditahun 2017 ada beberapa remaja yang meminumminuman keras pada acara pernikahan, sehingga terjadi sebuah kericuhan akibat dari sekelompok remaja yang sedang minum-minum dan ujung-ujungnya menimbulkan korban dan yang menjadi korban adalah salah satu orang tua. beliau bermaksud ingin menegur agar tidak meminum-minuman keras pada saat acara sedang berlangung namun siapa sangka remaja tersebut tidak terima dan malah memukul orang tua yang memberikan nasehat. dari permasalahan yang ada bisa kita lihat bahwa etika remaja didesa Lampuyang masih kurang dalam hidup lingkungan masyarakat dan rasa toleransi tidak bisa kita lihat lagi, perlu kita melihat bahwa hal seperti inilah sebenarnya yang harus kita hindarkan dikarenakan hanya akan menimbulkan sebuah kerugian, maka dengan itulah perlu kita pahami bagaimana etika yang baik didalam sebuah sistem masyarakat. Bukan hanya terkait etika yang menjadi permasalahan didesa Lampuyang Kecamatan Teluk Sampit namun terkait moral remaja disana juga mengalami kemunduran (Dewantara \& Nurgiansah, 2021).

Menurut Dr. Alexander Sonny Keraf dalam berita jambi.co pengertian moral adalah sebagai berikut. "moral adalah Moral dapat digunakan untuk mengukur kadar baik dan buruknya sebuah tindakan manusia sebagai manusia, mungkin sebagai anggota masyarakat (member of society) atau sebagai manusia yang memiliki posisi tertentu atau pekerjaan tertentu."

Karakter merupakan salah satu hal penting yang harus ada pada diri manusia, baik dalam kehidupan manusia sebagai makhluk individu maupun sebagai anggota 
masyarakat dan bangsa, sebab maju mundurnya sebuah masyarakat bergantung pada karakter manusianya. Secara etimologi istilah karakter berasal dari bahasa latin character, yang berarti watak, tabiat, sifat-sifat kejiwaan, budi pekerti, kepribadian dan akhlak. Istilah Karakter juga diadopsi dari bahasa latin kharakter, kharessian, dan xharaz, yang berarti tools for marking, to engraven dan pointed stake, yang kemudian dipahami sebagai stempel atau cap. jadi watak itu adalah sebuah stempel atau cap yang melekat pada diri seseorang (Musfah, 2011: 217). Karakter sebagai tanda-tanda kebaikan, dan kematangan moral seseorang, untuk mewujudkan karakter tersebut tidaklah mudah, karakter yang berarti mengukir hingga terbentuk pola itu memerlukan proses yang panjang, Berbicara mengenai pendidikan karakter maka cakupannya sangat luas, namun dalam pendidikan karakter tidak hanya menyangkut pada satu karakter saja, oleh karena itu dalam konteks kali ini adalah lebih fokus kepada karakter religius.

Religius merupakan kata dasar dari religi yang berasal dari bahasa asing religion sebagai bentuk dari kata benda agama atau kepercayaan akan adanya sesuatu kekuatan kodrati diatas manusia, sedangkan religious yang berarti sifat religi yang melekat pada diri seseorang, religius sebagai salah satu nilai karakter dideskriprikan oleh Suparlan sebagai sikap perilaku yang patuh dalam melaksanakan ajaran agama yang dianut, toleran terhadap agama lain

Peran kepala keluarga tentunya sangat dibutuhkan dalam pembentukan karakter religius remaja, di karenakan kepala keluarga adalah orang yang akan menjadi contoh anak-anaknya ketika sudah memasuki usia remaja, oleh karna itu untuk menunjang keberhasilan pembentukan karakter religius pada remaja, tentunya setiap keluarga dan terkhusunya kepala keluarga harus meciptakan suasana yang harmonis, rukun, dan damai, dikarenakan akan mempengaruhi tingkat psikologis dan karakter seorang remaja, begitu pula sebaliknya remaja yang kurang berbakti bahkan melakukan tindakan moral kemanusiaan, dibidani oleh ketidak harmonisan dalam lingkungan keluarga. Tentunya Orang tua yang bijaksana akan mendidik anak-anaknya dengan rasa cinta kasih dan sayang, agar menghasilkan anakanak yang berprestasi dan dapat diandalkan, dari pada dengan didikan yang didasarkan pada kewajiban atau tugastugas saja (Rachman et al., 2021).

Kenakalah remaja adalah ekspresi dan dorongan yang tidak terpuaskan (Kartono, 2003). Bagi pelaku kenakalan, tindakan menyimpangnya adalah respon normal terhadap hasrat batinnya, seperti orang yang tidak melakukan kenakalan kenakalan juga dikondisikan oleh berbagai situasi yang hadir dan berlaku disekitarnya. Selain itu kenakalan remaja bisa disebabkan berbagai faktor temanteman yang negatif, kedekatan dengan kekerasan, kecerdasan rendah, rekanrekan yang nakal, dan sifat-sifat genetika tertentu semua memainkan peran. Namun banyak penelitian menunjukkan bahwa unit keluarga merupakan penentu besar perilaku nakal pada saat remaja (Nurgiansah, 2021a).

Oleh karena itu dalam proses pembentukan karakter remaja, maka perlu juga sebagai orang tua mengajarkan dan menanamkan nilai-nilai agama yang dianutnya, oleh karna itu dimulai dari sekarang kepala keluarga sebagai orang yang mempunyai tanggung jawab besar harusnya sudah mulai menanamkan halhal kecil yang berbau posiitf kepada remaja-remaja agar menjadi kebiasaan yang baik, adapun maksud tujuan kepala keluarga sebagai fasilitator dan pembentuk karakter remaja adalah bertujuan untuk 
menumbuhkan dan meningkatkan keimanan melalui pemberian dan pemupukan pengetahuan, penghayatan, serta pengalaman sehingga menjadi manusia yang berkembang dalam hal keimanan, ketakwaan, berbangsa dan bernegara, serta patuh dalam melaksanakan ajaran agama yang dianutnya, toleran terhadap pelaksanaan ibadah agama lain, dan hidup rukun dengan agama lain.

\section{METODE PENELITIAN}

Penelitian ini dilakukan di Desa Lampuyang, Kabupaten Kota Waringin Timur Kecamatan Teluk Sampit. Jenis penelitian ini adalah penelitian deskritif dengan pendekatan kualitatif. dalam penelitian ini peneliti menggunakan pendekatan penelitian kualitatif yang menyajikan dan menggunakan kata-kata. Seperti yang dikatakan Bodgan dan Biglen (1982) dalam Sugiyono (2016:13), salah satu karakteristk penelitian kualitatif yaitu enelitian kualitatif yang bersifat deskriptif dan data yang terkumpul berbentuk katakata atau gambar sehingga tidak menekankan pada angka. Dengan menggunakan pendekatan penelitian kualitatif ini peneliti berharap dapat melakukan penelitian secara mendalam untuk memperoleh data yang akurat.

Dalam penelitian ini sumber data yang digunakan oleh peneliti adalah sumber data primer dan data sekunder. Sumber data primer adalah sumber data yang langsung memberikan data kepada pengumpul data, dan sumber sekuder merupakan sumber yang tidak langsung memberikan data kepada pengumpu data, misalnya lewat orang lain atau lewat dokumen (Nurgiansah, 2018).

Prosedur pengumpulan data ada penelitian ini adalah meliputi wawancara, observasi dan dokumentasi. Sebab bagi peneliti kualitatif fenomena dapat dimengerti maknanya secara baik, apabila dilakukan interaksi dengan subyek melalui wawancara mendalam dan observasi pada latar, dimana fenomena tersebut berlangsung dan di saming itu untuk melengkapi data, diperlukan dokumentasi (tentang bahan-bahan yang ditulis atau tentang subyek).

Wawancara adalah percakapan dengan maksud tertentu. Maksud digunakan wawancara antara lain adalah:

a. Mengkontruksi mengenai orang, kejadian, kegiatan, organisasi, perasaan, motivasi, tuntutan, kepedulian dan lain-lain.

b. Mengkontruksi kebulatan-kebulatan sebagai yang dialami pada masa lalu.

c. Memproyeksikan kebulatan-kebulatan sebagai yang telah di harapkan untuk dialami pada masa yang akan datang.

d. Memverifikasi, mengubah, dan memperluas kontruksi yang dikembangkan oleh peneliti sebagai pengecekan anggota. Dalam penelitian ini teknik wawancara yang digunakan adalah wawancara terbuka artinya bahwa dalam penelitian ini para subjeknya mengetahui bahwa mereka sedang diwawancarai dan mengetahui pula apa maksud dari wawancara itu, metode ini digunakan untuk memperoleh data tentang tentang peran keluarga dalam membentuk karakter religius (Nurgiansah, 2020a).

Observasi adalah pengamatan yang dilakukan secara sengaja, sistematis mengenai fenomena sosial dengan gejalagejala psikis untuk kemudian dilakukan pencatatan. Sanafiah Faisal yang dikutip Sugiyono (2013:310), mengklasifikasikan observasi menjadi observasi berpartisipasi (participant observation), observasi yang secara terang-terangan dan tersamar (overt observation and convert observation), dan observasi tak terstruktur (unstruktured observation), dalam penelitian ini, dicatat dalam Catatan 
Lapangan (CL), sebab catatan lapangan merupakan alat yang sangat penting dalam penelitian kualitatif. Dalam enelitian kualitatif, peneliti mengadakan pengamatan dan wawancara dalam pengumpulan data di lapangan. Pada waktu di lapangan dia membuat catatan setelah pulang kerumah atau tempat tinggal barulah menyusun catatan lapangan.

Dalam penelitian ini obervasi yang digunakan yaitu observasi terbuka yaitu dengan membuat catatan bebas tentang segala aktifitas yang berkaitan langsung dengan objek yang diteliti. Menurut Sugiyono (2016:240) menyatakan bahwa dokumen bisa berbentuk tulisan, gambar, atau karya-karya menumental dari seseorang. Dokumen yang berbentuk tulisan misalnya biografi, peraturan, dan kebijakan. Dokumen yang berbentuk gambar misalnya foto, gambar hidup, sketsa dan lain-lain. sudi dikumen merupakan pelengkap dari pengumpulan data dengan observasi dan wawancara. Dalam penelitian ini dokumentasi yang dimaksud adalah berkas-berkas atau arsip internal yang berkaitan dengan objek penelitian adapun dokumentasi yang diperoleh dalam penelitian ini berupa foto, video, rekaman suara, dan dokumen (Nurgiansah, 2021b).

Analisis data meliputi Reduksi Data, penyajian data, menarik kesimpulan. Mereduksi data berarti merangkum, memilih hal-hal yang pokok, memfokuskan pada hal-hal yang penting, dicari tema dan polanya. Dengan demikian data yang telah direduksi akan memberikan gambaran yang lebih jelas, dan mempermudah peneliti untuk melakukan pengumpulan data selanjutnya, dan mencarinya bila diperlukan. Setelah data direduksi, maka langkah selanjutnya adalah mendisplaykan data. Dalam penelitian kualitatif, penyajian data bisa dilakukan dalam bentuk uraian singkat, bagan, hubungan antar kategori.
Langkah ketiga dalam analisis data kualitatif adalah penarikan kesimpulan dan verifikasi. Kesimpulan awal yang dikemukakan masih bersifat sementara, dan akan berubah bila tidak ditemukan bukti-bukti yang kuat yang mendukung pada tahap pengumpulan data berikutnya. Tetapi apabila kesimpulan yang dikemukakan pada tahap awal, di dukung oleh bukti-bukti yang valid dan konsisten saat peneliti kembali ke lapangan mengumpulkan data, maka kesimpulan yang dikemukakan merupakan kesimpulan yang kredibel.

Pada penelitian ini untuk menguji keabsahan data dilakukan dengan teknik perpanjangan pengamatan dan triangulasi. Perpanjangan pengamatan berarti peneliti kembali kelapangan, melakukan pengamatan kembali, melakukan wawancara lagi dengan sumber data yang pernah ditemui atau sumber data yang baru. Dalam penelitian ini peneliti melakukan perpanjangan selama satu bulan dengan pengamatan kembali dilapangan untuk mengecek dan memastikan kembali apakah data yang sudah diperoleh itu sudah benar atau masih terdapat sebuah kesalahan. Triangulasi dalam uji kredibilitas ini diartikan sebagai pengecekkan data dari berbagai sumber dengan berbagai cara (Nurgiansah \& Widyastuti, 2020).

Dalam penelitian ini menggunakan teknik triangulasi yang digunakan triangulasi tekhnik dan triangulasi sumber. Triangulasi tekhnik merupakan uji kreadibilitas data yang dilakukan dengan cara mengecek data kepada sumber yang sama dengan tekhnik yang berbeda. Data yang di peroleh dengan wawancara, lalu dicek dengan observasi, dan dokumentasi sehingga dalam hal ini, data hasil wawancara dicek kebenarannya dengan data-data atau dokumen ataupun observasi. Adapun wawancara yang dimaksud dalam hal ini yaitu peran kepala 
keluarga dalam membentuk karakter religius anak didesa lampuyang kabupaten kota waringin timur.

Triangulasi sumber untuk menguji kreadibillitas data dilakukan dengan cara mengecek data yang diperoleh melalui beberapa sumber. Dalam hal ini triangulasi sumber dilakukan dengan cara membandingkann dan mengecek kebenaran dari suatu data yang diperoleh dari sumber data lainnya.

\section{HASIL PENELITIAN DAN PEMBAHASAN Hasil Penelitian}

Keluarga adalah suatu institusi yang terbentuk karena ikatan perkawinan. Di dalamnya hidup bersama pasangan suami-istri secara sah karena pernikahan (Syaiful Bahri Djamarah, 2014: 18) (Nurgiansah, 2020b). Keluarga dapat dipahami dari dimensi hubungan darah dan hubungan sosial. Jika dipahami dari dimensi hubungan darah, keluarga merupakan suatu kesatuan yang diikat oleh hubungan darah antara satu dengan yang lain. Berdasarkan dimensi ini, keluarga bisa dibedakan menjadi keluarga inti dan keluarga besar. Sementara dari dimensi sosial, keluarga merupakan satu kesatuan yang diikat oleh adanya saling berhubungan atau interaksi dan saling memengaruhi antara satu dengan lainya, walaupun di antara mereka tidak terdapat hubungan darah.

Ada beberapa fungsi keluarga yaitu sebagai tempat bernaung yang teduh, tempat belajar, tempat menjalin komunikasi, tempat kesenjangan, tempat belajar beribadah.

Peran dapat diartikan sebagai orientasi dan konsep dari bagian yang dimainkan oleh suatu pihak dalam oposisi sosial. Dengan peran tersebut, sang pelaku baik itu individu maupun organisasi akan berperilaku sesuai harapan orang atau lingkungannya, sehingga kemampuan atau kesiapan yang di miliki seorang untuk mempengarui, mendorong mengajak orang lain agar menerima pengaruh itu sendiri (Riyadi, 2002: 138).

Adapun pembagian peran menurut (Soekanto, 2001: 242) yaitu dibagi menjadi 3 sebagai berikut:

1. Peran aktif Adalah peran yang diberikan oleh anggota sekelompok karena kedudukannya didalam kelompok sebagai aktifitas kelompok, sebagai pengurus, pejabat, dan lainnya sebagai.

2. Peran aspiratif Adalah peran yang diberikan oleh anggota kelompok kepada kelompoknya yang memberikan sumbangan yang sangat berguna bagi kelompok itu sendiri.

3. Peran pasif Adalah sumbangan anggota kelompoky ang bersifat pasif, dimana anggota kelompok menahan diri agar memberikan kesempatan pada fungsi fungsi lain dalam kelompok sehingga berjalan dengan baik.

Adapun istilah kepala keluarga Menurut Kamus Besar Bahasa Indonesia (KBBI), kepala keluarga adalah orang yang bertanggung jawab terhadap suatu keluarga, yang mengurusi urusan-urusan dalam rumah tangga, sampai dengan pencarian nafkah, penjagaan hubungan rumah tangga dan masyarakat, dan urusan lain yang melibatkan rumah tangga dalam kehidupan sehari-hari.

Peran kepala keluarga dalam pembentukan karakter seorang remaja tentu itu sangat dibutuhkan, dikarenakan melihat seiring dengan perkembangan zaman, bisa kita lihat bahwa remaja-remaja sekarang pada khususnya mengalami yang namanya degradasi moral serta kurangnya etika yang baik didalam sebuah tatanan masyarakat, maka dari sekarang perlu menanamkan dan mengajarkan nilai-nilai agama, agar nantinya tetap berjalan sesuai dengan apa yang diajarkan didalam agamanya, oleh karna itu untuk menunjang proses pembentukan karakter ini maka 
perlu menanamkan sesuatu hal-hal yang berbau positif agar nantinya menjadi sebuah kebiasaan yang baik dan mampu diterapkan dalam berkehidupan.

Karakter adalah watak, tabiat, akhlak atau kepribadian seseorang yang terbentuk dari hasil internalisasiberbagai kebajikan yang diyakininya dan digunakannya sebagai landasan untuk cara pandang, berfikir, bersikap, dan bertindak (Puskur, 2010). Ada beberapa cara dalam proses pembentukan karakter diantaranya dengan memberikan pendidikan karakter.

Nilai karakter yang berkaitan dengan ranah hubungan manusia dengan Tuhan Yang Maha Esa adalah nilai religius. Ranah religius sangat penting untuk ditumbuh kembangkan dalam rangka mengonstruk perkataan, pikiran, serta tindakan yang diusahakan untuk selalu didasarkan pada nilai dan norma ketuhanan yang berdasarkan pada ajaran agama yang dianut.

Secara etimologis, kata karakter (Inggris: character) berasal dari bahasa Yunani, yaitu charassein yang berarti "to engrave" (Kevin Ryan \& Karen E. Bohlin,1999). Kata "to engrave" dapat diterjemahkan "mengukir, melukis" (John M. Echols dan Hassan Shadily, 1995). Makna ini dapat dikaitkan dengan persepsi bahwa karakter adalah lukisan jiwa yang termanifestasi dalam perilaku. Menurut Maxwell, karakter jauh lebih baik dari sekedar perkataan. Lebih dari itu, karakter merupakan sebuah pilihan yang menentukan tingkat kesuksesan. Karakter atau watak adalah sifat batin yang mempengaruhi segenap pikiran, prilaku, budi pekerti, dan tabiat yang dimiliki manusia atau makhluk hidup lainnya. Menurut Doni Kusuma, karakter adalah sebuah gaya, sifat, ciri, maupun karakteristik yang dimiliki seseorang yang berasal dari bentukan atau tempaan yang didapatkannya melalui lingkungan sekitarnya.
Karakter dalam Kamus Besar Bahasa Indonesia diartikan dengan "tabiat, sifat-sifat kejiwaan, akhlak atau budi pekerti yang membedakan seseorang dengan yang lain, dan watak (Pusat Bahasa Departemen Pendidikan Nasional,2008). Orang berkarakter berarti orang yang berkepribadian, berperilaku, bersifat, bertabiat, atau berwatak. Makna seperti itu menunjukkan bahwa karakter identik dengan kepribadian atau akhlak. Kepribadian merupakan ciri atau karakteristik atau sifat khas dari diri seseorang yang bersumber dari bentukanbentukan yang diterima dari lingkungan, misalnya keluarga pada masa kecil, dan juga bawaan sejak lahir (Doni A. Koesoema, 2007).

Adapun bentuk - bentuk karakter religius yaitu: a) Sikap dan perilaku yang patuh dalam melaksanakan ajaran agamnya. b) Toleran terhadap pelaksanaan ibadah agama lain Keberagaman suku, ras, dan agama merupakan salah satu ciri khas yang dimiliki oleh bangsa Indonesia. c) Hidup rukun dengan pemeluk agama lain.

\section{Pembahasan}

Setelah melakukan penelitian dan mengumpulkan data yang diperoleh melalui observasi, wawancara, dan dokumentasi, maka selanjutnya peneliti menganalisis data dari hasil penelitian di Desa Lampuyng Kecamatn Teluk Sampit, Kabupaten Kota Waringin Timur.

Kepala keluarga ini merupakan orang yang bertanggung jawab atas anggota keluarganya atas kebutuhan sehari-hari, yang mempunyai peran penting dalam keluarga seperti halnya dalam mendidik anak yang sudah bisa dikatakan remaja, tentu peran kepala keluarga sangat dibutuhkan dalam medidik remaja terkhususnya dalam membentuk karakter remaja mengingat sekarang bahwa banyak sekali permasalahan yang 
terjadi pada saat ini tidak usah jauh-jauh kita melihat Berdasarkan realitas yang ada. Secara etimologi istilah karakter berasal dari bahasa latin charakter, yang berarti tabiat, sifat-sifat kejiwaan, budi pekerti, kepribadian dan akhlak. Karakter menurut bahasa latin juga diartikan Kharessian, dan Xharaz, yang berarti tools for marking, to engraven dan pointed stake, yang kemudian dipahami sebagai sifat-sifat yang melekat pada diri seseorang. Karakter sebagai tanda-tanda kebaikan, dan kematangan moral seseorang, untuk mewujudkan karakter tersebut tidaklah mudah, karakter yang berarti mengukir hingga terbentuk pola itu memerlukan proses yang panjang.

Religius merupakan kata dasar dari religi yang berasal dari bahasa asing religion sebagai bentuk dari kata benda agama atau kepercayaan akan adanya sesuatu kekuatan kodrati diatas manusia, sedangkan religious yang berarti sifat religi yang melekat pada diri seseorang.

Dari hasil penelitian yang penulis lakukan maka dapat dilihat bagaimana peran kepala keluarga dalam membentuk karakter religius remaja, dalam rangka untuk membentuk karakter religius upayaupaya yang dilakukan memang harus melalui proses yang sangat panjang dimulai dari:

1. Memperkenalkan pengetahuan tentang agama,

2. Mengajarkan kebiasaan-kebiasaan yang baik,

3. Mengajak untuk membiasakan hal-hal baik,

4. Mengingatkan apabila ada kesalahan ataupun kekurangan dalam sistem penerapannya, dan ini memang merupakan salah satu peran kepala keluarga dalam upaya membentuk karakter religus remaja.

Oleh karena itu selain upaya-upaya yang dilakukan secara terus menerus juga didukung dalam sistem penanaman karakter religius. Dan Dalam sistem penanaman karakter religius ini dimulai dari:

1. Orang tua atau kepala keluarga itu sendiri dimana sebagai orang tua harus memberikan contoh yang baik untuk remaja-remaja pada saat ini agar bisa menimbulka karakter yang positif untuk remaja-remaja seperti halnya kepala keluarga memperlihatkan sikap baik kepada orang-orang secara otomatis maka remaja akan terpengaruh dengan sifat teladan dari kepala keluarga tersebut,

2. Lingkungan keluarga tentu didalam sebuah lingkungan keluarga agar mampu menunjang dalam menanamkan atau membentuk karakter harus membiasakan hal-hal yang positif sehingga dari lingkungan keluarga pun remaja-remaja sudah diajarakn untuk melakukan hal- hal positif, kemudian setelah melalui orang tua dan lingkungan dari keluarga selanjutnya harus didukung dengan pemberian,

3. Pendidikan tentang agama yang dimana remaja - remaja sekarang adalah tunas muda pemegang tonggak peradaban dimana ditangan mereka diharapkan tercipta sebuah perubahan dan harapan besar ini tak kan mudah terwujud apabila para remaja mengalami krisis pemahaman dana keimanan.

Oleh karena itu hanya melalui pendidikan agama diberikan pemahaman yang mendalam dan menjadikan prilaku remaja- remaja terkhusunya lebih terarah. Dan didalam pendidikan agama inilah remaja dibiasakan dan diajarkan dengan hal-hal yang positif seperti ibadah bareng, berbuat baik kepada sesama, toleran terhadap umat beragama dan lain-lain. peneliti melihat setelah dilakukannya berbagai upaya dalam membentuk 
karakter reliigus remaja di desa Lampuyang peneliti melihat adanya sebuah perubahan terhadap karakter remajaremaja ini bisa dilihat dengan berkurangnya remaja- remaja yang mengkonsumsi obat- obatan maupun minuman-minuman, dll, serta didukung dengan keaktifaan remaja - remaja dalam bidang agama.

Faktor apa saja yang menjadi penghambat dan pendukung peran kepala keluarga dalam membentuk karakter religius remaja di desa Lampuyang Kabupaten Kota Waringin Timur. Proses pembentukan karakter religius memang bukanlah sesuatu hal yang mudah yang dimana butuh sebuah proses panjang dalam membentuk karakter sehingga dalam proses pembentukan karakter ini ada beberapa faktor yang berpengaruh yang dimana bisa kita lihat bahwa ada faktor penghambat dan faktor pendukung.

\section{Faktor penghambat}

Faktor penghambat dalam membentuk karakter religius remaja didesa Lampuyang Kabupaten Kota Waringin Timur yaitu:

1. Konsistensi, Kebanyakan dari kepala keluarga maupun orang tua pada saat ini tidak memiliki rasa konsisten dalam membentuk karakter remaja sehingga dalam sitem pembentukan karakter pada remaja tidak maksimal.

2. Sikap remaja yang masih labil, Tentu sikap remaja yang masih labil ini tentu menyusahkan dalam membentuk karakter remaja membutuhkan kesabaran yang sangat tinggi dan konsistensi dalam penerapannya sehinggga harus membutuhkan komunikasi yang baik agar dapat menanganinya.

3. Pengaruh jaman dan kemajuan tekhnologi, Seperti yang kita ketahui pengaruh jaman dan tekhnologi sekaarang sudah berkembang dengan begitu pesat sehingga dalam membentuk karakter remaja sangat sulit karen remaja-remaja sekarang dibutakan akan tekhnologi dan lupa akan tanggung jawabnya sehingga sebagai orang tua wajib melakukan filterisasi atau pengontrolan terhadap perkembangan zaman dan kemajuan tekhnologi.

4. Pembiaran dari orang tua, orang tua berperan dalam pembentukan karakter sehingga sebagai orang tua patutnya sadar dan tidak melakukan pembiaran dalam membentuk karakter religius remaja.

\section{Faktor pendukung}

Faktor pendukung dalam membentuk karakter religius remaja di desa lampuyang kabupaten kota waringin timur yaitu:

1. Adanya dukungan dari orang tua, adanya dukungan dari orang tua merupakan salah satu faktor pendukung dalam membentuk karakter karena melalui orang tua lah remajaremaja banyak diajarkan sesuatu hal dan melalui orang tua lah watak dan kepribadian remaja dibentuk.

2. Lingkungan, lingkungan merupakan salah satu faktor pendukung dalam membentuk karakter religius karena apabila lingkungan masyarakat positif maka karakter yang terbangun dikalangan remaja juga positif lingkungan ialah suatu yang melingkupi tubuh yang hidup, lingkungan pergaulan adalah faktor yang sangat penting dalam pendidikan akhlak sebaik apapun pembawaan, kepribadian, keluarga, pendidikan yang ditempuh, tanpa didukung oleh lingkungan yang kondusif maka karakter yang baik tidak akan terbentuk.

3. Adanya guru, dengan adanya guru menjadi salah satu faktor pendukung 
dalam membentuk karakter remaja karena guru merupakan orang yang juga bertanggung jawab dalam pembentukan pribadi remaja selama berada dilingkungan pendidikan.

\section{KESIMPULAN}

Berdasarkan hasil penelitian dan pembahasan dalam penelitian ini dapat disimpulkan bahwa peran kepala keluarga dalam membentuk karakter religius remaja di desa Lampuyang Kabupaten Kota Waringin Timur dengan upaya-upaya yang dilaksanakan mulai dari (1) memberikan atau memperkenalkan pengetahuan tentang agama, (2) mengajarkan sekaligus mengajak untuk melakukan kebiasaankebiasaan baik pada remaja-remaja, (3) memberitahu manfaat dan tujuan melakukan hal-hal yang baik pada remaja, (4) dan terakhir mengingatkan apabila ada kesalahan atau kekurangan dalam sistem penerapannya, dan kemudian dalam sistem menanamkan karakter religius pada remaja-remaja memang harus dimulai dari orang tua atau kepala keluarga itu sendiri, yang kemudian melalui lingkungan keluarga, dan yang terakhir melakukan pemberian pendidikan tentang agama.

Faktor penghambat dan pendukung yang dihadapi oleh kepala keluarga yaitu faktor penghambat (1) kurangnya konsistensi orang tua maupun anak dalam sistem penerapannya, (2) pengaruh sikap remaja yang masih labil, (3) pengaruh jaman dan kemajuan tekhnologi, adanya pembiaran dari orang tua.

Sedangkan faktor pendukungnya yaitu (1) adanya dukungan dari orang tua, (2) lingkungan, (3) adanya guru. Adapun cara kepala keluarga dalam menangani faktor penghambat dalam membentuk karakter religius remaja yaitu melalui komunikasi yang baik terhadap remaja serta mempunyai rasa konsisten terhadap apa yang ingin dilaksanakan, sehingga dapat melakukan filtrasi terhadap perkembangan zaman dan menumbuhkan keinginan remaja untuk belajar lebih baik sehingga remaja-remaja mempunyai karakter yang lebih baik dan berguna bagi bangsa dan negara.

Berdasarkan penelitian ini maka penulis memberikan saran kepada:

1. Kepala keluarga diharapkan berupaya dengan kemampuan yang lebih kepada remaja- remaja dalam membentuk karakter religius baik melalui pengajarannya maupun dalam sistem penerapannya.

2. Kepala keluarga diharapkan lebih bisa konsisten dalam membentuk karakter religius remaja.

3. Kepala keluarga diharapkan mampu memanfaatkan kemajuan tekhnologi dan perkembangan zaman dalam membentuk karakter religius remaja remaja.

4. Kepala keluaga diharapkan selalu mendoakan anak-anaknya dalam ibadah sholatnya.

5. Untuk masa yang akan datang penulis mengharapkan ada peneliti yang meniliti terkait dengan pola-pola dalam pembentukan karakter pada remaja dari perspektif masing-masing agama sehingga penjabaran pembahasan lebih luas dan lebih lengkap lagi agar pendidikan karakter menjadi kebutuhan dinegara ini.

\section{DAFTAR PUSTAKA}

Abdul, Madjid. (2011). Pendidikan Karakter Perspektif Islam. Bandung: Rosdakarya.

Anwar, Muhammad Khairul. 2017. Peran keluarga dalam membentuk anak surat an-nahl ayat 72.

Asmani, Jamal Ma'mur. 2011. Buku Panduan Internalisasi Pendidikan Karakter di Sekolah. Jogjakarta: Diva Press. 
Azzet, Akhmad Muhaimin, Urgensi Pendidikan Karakter Di Indonesia: Revitalisasi Pendidikan Karakter Terhadap Keberhasilan Dan Kemajuan Bangsa (Jogjakarta: Ar-Ruzz Media, 2013).

Balitbang, Puskur. 2010. Pembinaan Pendidikan Karakter Di Sekolah Menengah Pertama, Jakarta.

Bogdan, "Teknik Analisis Data", dalam Sugiyono, Metode Penelitian Pendidikan Pendekatan Kuantitatif Kualitatif dan R\&D. Bandung, Alfabeta, 2016.

Bogdan, Robert C. \& Biklen, Sari Knopp. (1982). Qualitative Research for Education: An Introduction to Theory and Methods. Boston: Allyn and Bacon Inc.

Cahyono, Heri -Pendidikan Karakter: Strategi Pendidikan Nilai Dalam Membentuk Karakter Religius, Ri'ayah, no. 01 (July 2016).

Dewantara, J. A., \& Nurgiansah, T. H. (2021). Strengthening Pancasila Values During the Covid19 Pandemic. Edukatif: Jurnal Ilmu Pendidikan, 3(4), 2411-2417.

Djamarah, Syaiful Bahri. 2014. Pola Asuh Orang Tua Dan Komunikasi Dalam Keluarga : Upaya Membangun Citra Membentuk Pribadi Anak.

Indrianti, Tia. 2020. Peran orang tua dalam membentuk karakter anak didesa kedaton induk kecamatan batanghari nuban lamung timur.

Kartono, Kartini. 2003. Kenakalan Remaja. Depok: PT Raja Grafindo Persada

Keraf, Sonny. 1998. Etika Bisnis Tuntunan dan Relevansinya, Yogyakarta, Kanisius.

Koeseoma, Doni A. 2007. Pendidikan Karakter: Strategi Mendidik Anak Di Zaman Old. Jakarta.

Meulidya, Firunika Ratna. 2018. Hubungan peranan keluarga dengan kenakalan remaja pada siswa siswi kelas XI di sma negri 1 rumpang.

Miles, M. B. \& Huberman, M. (1992). Analisis Data Kualitatif. Jakarta: Penerbit Universitas Indonesia

Miles, M.B \& Huberman A.M. 1984, Analisis Data Kualitatif. dalam Sugiyono, Metode Penelitian Pendidikan Pendekatan Kuantitatif Kualitatif dan R\&D. Bandung, Alfabeta, 2016.

Moleong, L.J. 2013. Metode Penelitian Kualitatif. Edisi Revisi. Bandung. PT Remaja Rosdakarya.

Moleong, L.J. 2017. Metodologi Penelitian Kualitatif. Edisi Revisi Bandung: PT Remaja Rosdakarya.

Mu'in, Fatchul. (2011). Pendidikan Karakter: Kontruksi Teoretik \& Praktik. Yogyakarta: ArRuzz Media.

Muslich, Masnur. (2011). Pendidikan Karakter: Menjawab Tantangan Krisis Multidimensional. Jakarta: PT Bumi Aksara.

Nashir, Hadedar, 2013 Yogyakarta: Multi Presindo "Pendidikan Karakter Berbasis Agama dan Budaya", Yogyakarta: Multi Presindo, hlm 22-24

Nurgiansah, T. H. (2018). Pengembangan Kesadaran Hukum Berlalu Lintas Siswa Melalui Model Pembelajaran Jurisprudensial Dalam Pendidikan Kewarganegaraan (Studi Kasus di SMK Bina Essa Kabupaten Bandung Barat Kelas X Administrasi Perkantoran). Tesis. Repository Universitas Pendidikan Indonesia, Oktober. http://ieeeauthorcenter.ieee.org/wp-content/uploads/IEEE-ReferenceGuide.pdf\%0Ahttp://wwwlib.murdoch.edu.au/find/citation/ieee.html\%0Ahttps://doi.or g/10.1016/j.cie.2019.07.022\%0Ahttps://github.com/ethereum/wiki/wiki/WhitePaper\%0Ahttps://tore.tuhh.de/hand

Nurgiansah, T. H. (2020a). Fenomena Prostitusi Online Di Kota Yogyakarta Dalam Persfektif Nilai Kemanusiaan Yang Adil Dan Beradab. Jurnal Kewarganegaraan, 17(1), 27-34. https://doi.org/10.24114/jk.v17i1.14208 
Nurgiansah, T. H. (2020b). Filsafat Pendidikan. In Banyumas: CV Pena Persada.

Nurgiansah, T. H. (2021a). Pemanfaatan E-Learning Dalam Pembelajaran Pendidikan Kewarganegaraan. JINTECH: Journal of Information Technology, 2(2), 138-146.

Nurgiansah, T. H. (2021b). Pendidikan Pancasila. In Solok: CV Mitra Cendekia Media.

Nurgiansah, T. H., \& Widyastuti, T. M. (2020). Membangun Kesadaran Hukum Mahasiswa PPKn UPY Dalam Berlalu Lintas. Civic Edu: Jurnal Pendidikan Kewarganegaraan Universitas Pasundan, 2(2), 97-102. https://doi.org/10.1017/CB09781107415324.004

Pusat Bahasa Departemen Pendidikan Nasional. (2008). Kamus Besar Bahasa Indonesia.Cet. I, Jakarta: Pusat Bahasa.

Rachman, F., Nurgiansah, T. H., \& Kabatiah, M. (2021). Profilisasi Pendidikan Kewarganegaraan dalam Kurikulum Pendidikan Indonesia. Edukatif: Jurnal Ilmu Pendidikan, 3(5), 2970-2984.

Rahmatin, Wiwin. 2017. Peran keluarga dalam membina karakter anak di rt 02 rw 02 kelurahan nobang baru kecamatan marga tiga lampung timur.

Ramli, T, 2003, Pendidikan Karakter. Bandung: Angkasa

Riyadi. Dodi Slamet. 2002. Pengembangan wilayah: teori dan konsep dasar. jakarta: pusat pengkajian kebijakan teknologi pengembangan wilayah BBPT.

Rosyid, Nur. 2016 dkk, Pendidikan Karakter Wacana dan Kepengaturan (Yogyakarta: Mitra Media, hlm. 15

Ryan, Kevin \& Karen E. Bohlin. 1999). Building Character in Schools: Practical Ways to Bring Moral Instruction to Life. San Francisco: Jossey Bass.

Soekanto. Soerjono. 2001. Sosiologi keluarga. PT Rineka Cipta.

Sugiyono. 2008. Metode Penelitian Kuantitatif Kualitatif dan R\&D. Bandung: Alfabeta.

Sugiyono. 2012. Metode Penelitian Kuantitatif, Kualitatif dan R\&D. Bandung: Alfabeta.

Sugiyono. 2016. Metode Penelitian Kuantitatif, Kualitatif, dan R\&D. Bandung: Alfabeta.

Suparlan, Mendidik Karakter Membetuk Hati, (Jakarta: AR-RUZZ MEDIA, 2012), h.

Syaroh, Lyna D.M. Membentuk karakter religius dengan pembiasaan perilaku religi di sekolah studi SMA negri 3 ponorogo

Thomas, Lickona. (1991). Educating for Character: How Our School Can Teach Respect and Responsibility. New York: Bantam books.

W, Ageng Aryyandhika. (2016). Pendidikan karakter dalam keluarga untuk membentuk kepribadian remaja yang dewasa dalam berpikir dan berprilaku.

Wiersma William, "Trianggulasi”, dalam Sugiyono, Metode Penelitian Pendidikan Pendekatan Kuantitatif Kualitatif dan R\&D. Bandung, Alfabeta 